\author{
슈퍼듀플렉스 스테인리스강의 반복 수정용접이 기계적 \\ 물성과 공식저항성에 미치는 영향 \\ 김유성 ${ }^{1,2} \cdot$ 남성길 ${ }^{1} \cdot$ 최명환 $^{2} \cdot$ 강남현 $^{2, *}$ \\ 1삼성중공업, 생산기술연구센터 \\ 2부산대학교, 재료공학부
}

\title{
Effect of Repeated Repair Welding on the Mechanical Properties and Pitting Corrosion Resistance of Super Duplex Stainless Steel
}

\begin{abstract}
Yusung Kim ${ }^{1,2}$, Seongkil Nam${ }^{1}$, Myeonghwan $\mathrm{Choi}^{2}$, and Namhyun Kang,**
${ }^{1}$ Samsung Heavy Industries CO., LTD, Production Technology Research center, Geoje-si 53261, Republic of Korea. ${ }^{2}$ Pusan National University, Department of Materials Science and Engineering, Busan 46241, Republic of Korea

Abstract: The study investigated the effect of repeated repair welding on the mechanical properties and pitting corrosion resistance of $25 \% \mathrm{Cr}$ super duplex stainless steels (UNS S32750). The test coupons were prepared by gas tungsten arc welding (GTAW) with ER2594 filler metal and repaired 3-times at the same weld locations, where the remaining previous welds were $2-3 \mathrm{~mm}$ in depth. The number of repairs provided various reheating to the original welds (as-welded condition) and to the previously repaired welds. The effect of repair welding reheating on the microstructure, ferrite content, hardness, impact toughness and pitting corrosion was investigated. The pitting corrosion occurred in the root region of the first repair weld (R1). Secondary phases such as austenite $\left(\gamma_{2}\right)$ and sigma $(\sigma)$ were observed in the reheated regions with a consumption of ferrite content, where impact toughness and pitting corrosion resistance were significantly reduced. The vicinity of the pitting corrosion region was analyzed, and showed that sigma $(\sigma)$ was precipitated in the secondary austenite $\left(\gamma_{2}\right)$ and at the boundary between ferrite and austenite. The fraction of the sigma phase was determined by electron back scatter diffraction (EBSD) to be $0.3 \%$ in the vicinity of the pitting corrosion region. This study also discusses the applicability of 3-times repair welding in the offshore industry.
\end{abstract}

(Received October 18, 2021; Accepted November 4, 2021)

Keywords: super duplex stainless steel, pitting corrosion, repair welding, GTAW, sigma phase

\section{1. 서 론}

슈퍼듀플렉스 스테인리스강은 내공식지수(Pitting Resistance Equivalent Number; PREN)가 40이 넘는 재질로 기존 오 스테나이트계 스테인리스강 보다 내공식성과 강도가 뛰어 나 해수 분위기 등의 부식환경에서 압력용기, 저장탱크 및 배관의 주요 재질로 사용된다. 부재를 접합하는 데에는 제 작 환경에 따라 다양한 용접 공법이 사용되며, 특히 용접

- 김유성: senior engineer - 석사과정, 남성길: senior engineer, 최명환: 박사과정, 강남현: 교수

*Corresponding Author: Namhyun Kang

[Tel: +82-51-510-3027, E-mail: nhkang@pusan.ac.kr]

Copyright (C) The Korean Institute of Metals and Materials
부와 열영향부(Heat Affected Zone; HAZ)의 기계적 물성 과 내공식성 등에 대해 많은 선행 연구가 진행되었다 [113]. 또한, 기존 용접부의 결함 등으로 인한 수정용접시 기 존 용접부와 열영향부의 재가열로 인한 특성 변화에 대한 선행 연구도 진행되었다 $[14,15]$. 해당 선행연구에서는 추 가 용접에 의해 발생한 재가열로 페라이트 분율이 줄어들 면서 이차오스테나이트 $\left(\gamma_{2}\right.$, secondary austenite $)$ 와 시그마 $(\sigma$, sigma)상이 생성되어 충격인성이 감소하고 공식이 발 생하는 임계공식온도(Critical Pitting Temperature; CPT)가 낮아지는 경향을 확인하였다.

Norsok M-601 규격은 슈퍼 듀플렉스 스테인리스강의 동 일위치에서 한 번의 수정용접만 허용한다 [16]. Shell과 같 은 Oil Major 회사의 용접과 관련된 사양서(Specification) 
Table 1. Chemical composition of base material and welding consumable (wt. \%)

\begin{tabular}{ccccccccccc}
\hline & $\mathrm{C}$ & $\mathrm{Si}$ & $\mathrm{Mn}$ & $\mathrm{Cr}$ & $\mathrm{Ni}$ & $\mathrm{Mo}$ & $\mathrm{Cu}$ & $\mathrm{N}^{2}$ & $\mathrm{PREN}^{\dagger}$ \\
\hline UNS32750 & 0.020 & 0.41 & 0.77 & 24.9 & 6.8 & 3.8 & 0.30 & 0.28 & 42 \\
ER2594 & 0.01 & 0.38 & 0.57 & 25.1 & 9.2 & 4.0 & 0.09 & 0.24 & 42.1 \\
\hline
\end{tabular}

PREN $=\% \mathrm{Cr}+3.3 \% \mathrm{Mo}+16 \% \mathrm{~N}$

Table 2. Mechanical properties, ferrite fraction and pitting corrosion of materials in the study

\begin{tabular}{ccccc}
\hline & $\begin{array}{c}\text { Impact } \\
\text { toughness }\end{array}$ & Hardness & $\begin{array}{c}\text { Ferrite } \\
\text { fraction }\end{array}$ & $\begin{array}{c}\text { Pitting } \\
\text { corrosion }\end{array}$ \\
\hline UNS32750 & $\begin{array}{c}107 \mathrm{~J} \\
\left(-46^{\circ} \mathrm{C}\right)\end{array}$ & $334\left(\mathrm{HV}_{10}\right)$ & $51 \%$ & $\begin{array}{c}\text { No pitting } \\
\left(50^{\circ} \mathrm{C}\right)\end{array}$ \\
ER2594 & $\begin{array}{c}184 \mathrm{~J} \\
\left(-50^{\circ} \mathrm{C}\right)\end{array}$ & $272\left(\mathrm{HV}_{10}\right)$ & $58.4 \%$ & $\begin{array}{c}\text { No pitting } \\
\left(40^{\circ} \mathrm{C}\right)\end{array}$ \\
\hline
\end{tabular}

는 조건부로 최대 두 번의 수정용접만 허용한다. 일부 해 양 프로젝트 사양서는 예상되는 최대 횟수의 열 이력을 포 함하는 용접 절차 시방서 보증 시험(Welding procedure qualification test)을 요구하고 있다. 이러한 규제는 재가열 로 인한 용접부내 금속간 화합물이나 석출물(시그마상, 카 이상, 크롬 탄화물 등)이 생성되어 기계적 물성 및 내공식 성을 저하시켜 실제 운영 중에 품질 문제로 발생될 가능성 이 높기 때문이다. 최근 해양 배관재는 제작 중에 기존 자 재의 수급이 어려워져 불량 용접부의 교체가 불가한 사유
가 자주 발생하여, 동일 용접부에서 두 번 이상의 수정용 접이 필요한 상황이 발생하고 있다. 따라서, 본 연구는 동 일위치에서 세 번 수정한 용접부와 기존 용접부 비교를 통 해 반복된 수정용접이 기계적 물성과 내공식성에 미치는 영향을 연구하였다.

\section{2. 실험 방법}

본 실험에서 사용된 모재는 $500(\mathrm{~L}) \times 250(\mathrm{~W}) \times 10(\mathrm{~T}) \mathrm{mm}$ 의 슈퍼듀플렉스 스테인리스강(UNS S32750)이며, 용접재료 는 gas tungsten arc welding (GTAW)용 AWS A5.9 ER2594를 사용하였다. 모재와 용접재료의 화학적 조성, 충 격값, 경도값, 페라이트 분율 및 공식 시험 결과는 자재 성적서를 기준으로 각각 표 1과 표 2에 나타내었다.

그림 1은 용접 적층 순서 및 형상을 나타낸다. Original 용접부는 총 14 패스로 제작하였고, 수정 용접은 그 전 용접부에서 $2-3 \mathrm{~mm}$ 의 기존 용접부를 남기고 나머지는 제 거한 후 수행하였다. 수정용접은 총 3 회까지 수행하였고, (a)

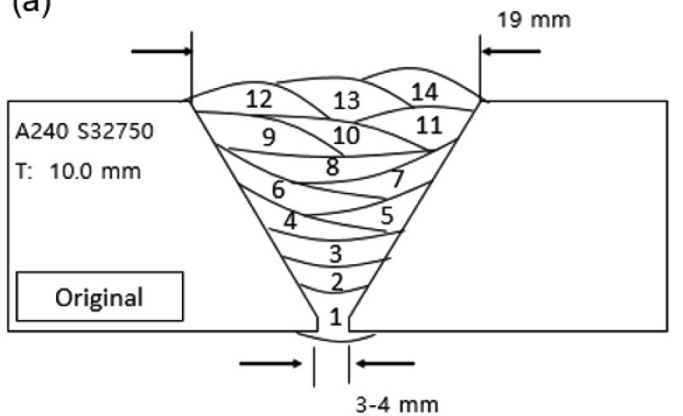

(c)

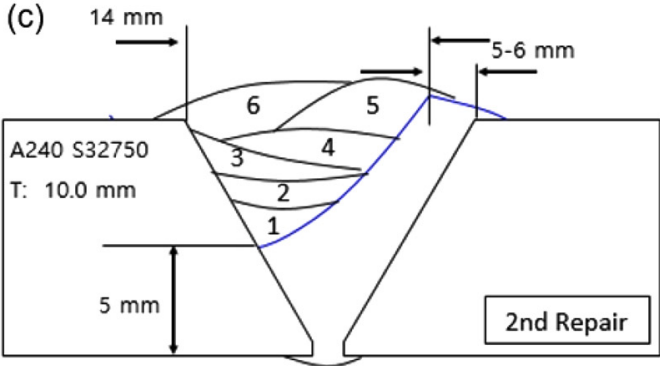

(b) $16-17 \underline{\mathrm{mm}}$

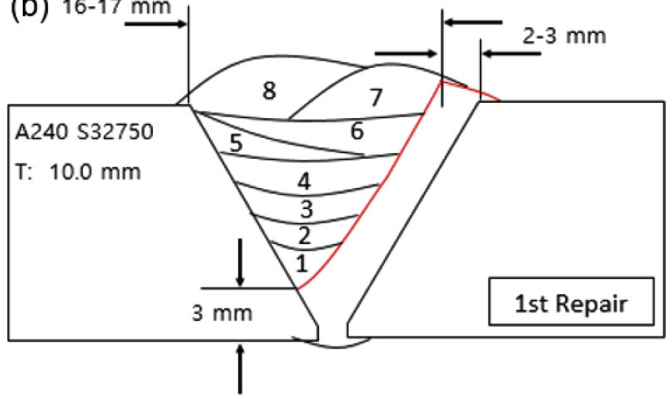

(d)

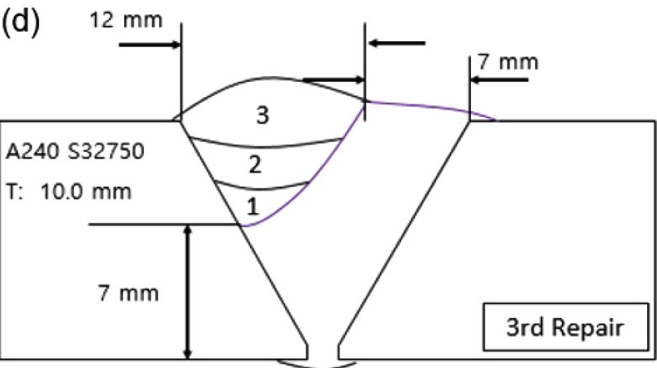

Fig. 1. Welding joint configuration for various specimens: (a) Original welding (OL), (b) $1^{\text {st }}$ Repair welding (R1), (c) $2^{\text {nd }}$ Repair welding (R2), (d) $3^{\text {rd }}$ Repair welding (R3). 
Table 3. Welding conditions applied in the study

\begin{tabular}{|c|c|c|c|c|c|}
\hline & & $\begin{array}{l}\text { Current } \\
\text { (A) }\end{array}$ & $\begin{array}{l}\text { Voltage } \\
\text { (V) }\end{array}$ & $\begin{array}{c}\text { Speed } \\
(\mathrm{cm} / \mathrm{min})\end{array}$ & $\begin{array}{c}\text { Heat Input } \\
(\mathrm{kJ} / \mathrm{mm})\end{array}$ \\
\hline \multirow{3}{*}{$\begin{array}{c}\text { Original } \\
\text { weld } \\
(\mathrm{OL})\end{array}$} & $\begin{array}{l}\text { Root } \\
\text { (1 Pass) }\end{array}$ & 70 & 8.5 & 3.2 & 1.10 \\
\hline & $\begin{array}{c}\text { Fill } \\
(2-11 \text { Pass })\end{array}$ & $126-151$ & $9.5-10.5$ & $11.4-16.0$ & $00.50-0.84$ \\
\hline & $\begin{array}{c}\text { Cap } \\
(12-14 \\
\text { Pass })\end{array}$ & 151 & $10.5-10.7$ & $10.3-11.2$ & $20.86-0.92$ \\
\hline \multirow{2}{*}{$\begin{array}{c}1^{\text {st }} \text { Repair } \\
\text { (R1) }\end{array}$} & $\begin{array}{c}\text { Fill } \\
(1-6 \text { Pass })\end{array}$ & $123-179$ & $9.2-11.0$ & $7.5-14.7$ & $0.46-1.14$ \\
\hline & $\begin{array}{c}\text { Cap } \\
\text { (7-8 Pass) }\end{array}$ & 150 & 10.5 & $8.7-9.7$ & $0.97-1.08$ \\
\hline \multirow{2}{*}{$\begin{array}{c}2^{\text {nd }} \text { Repair } \\
\text { (R2) }\end{array}$} & $\begin{array}{c}\text { Fill } \\
(1-4 \text { Pass })\end{array}$ & $135-150$ & $10.0-10.6$ & $9.5-10.4$ & $0.82-0.96$ \\
\hline & $\begin{array}{c}\text { Cap } \\
\text { (5-6 Pass) }\end{array}$ & 150 & 10.6 & $9.5-9.7$ & $0.99-1.01$ \\
\hline \multirow{2}{*}{$\begin{array}{c}3^{\text {rd }} \text { Repair } \\
\text { (R3) }\end{array}$} & $\begin{array}{c}\text { Fill } \\
(1-2 \text { Pass })\end{array}$ & 149 & $10.2-10.6$ & $9.9-10.1$ & $0.90-0.95$ \\
\hline & $\begin{array}{c}\text { Cap } \\
\text { (3 Pass) }\end{array}$ & 170 & 11.0 & 10.1 & 1.11 \\
\hline
\end{tabular}

이는 수정 용접 시 재가열로 인한 용접부 및 열영향부의 기계적 물성 및 공식저항성에 대한 영향 평가를 하기 위함 이다.

용접은 GTAW 공법으로 다층용접을 적용하였으며 보호 가스는 혼합가스 $\left(\mathrm{Ar}+2 \% \mathrm{~N}_{2}\right)$ 그리고 이면 퍼징가스로 $\mathrm{Ar}$ 을 사용하였다. 별도의 예열없이 상온에서 진행되었으며 층 간온도는 $35^{\circ} \mathrm{C}$ 이하로 관리하고 용접 후 강제 공냉을 하 였으며, 수정용접 시 입열량(heat input)은 최대한 유사하도 록 조절하였다. 용접 세부 조건은 표 3에 나타내었다.

용접부와 열영향부의 미세조직은 Original 시험편과 R3 시험편에서 정밀 분석하였고, ASTM E407에 따라 정밀 연마 후 $20 \mathrm{~g} \mathrm{NaOH}+100 \mathrm{ml}$ 수용액으로 에칭하여 200배 율과 500배율의 광학현미경으로 관찰하였다. 페라이트 분 율은 ASTM E562에 따라 36 개 영역을 정사각형의 격자 로 나누어 각 field별 16 개 지점에서 측정하였고 $\mathrm{OL}$ 시험 편과 R3 시험편에서 각각 용접부와 열영향부를 비교하였
다. 모재의 페라이트 분율은 $\mathrm{OL}$ 시험편의 두께 $1 / 2$ 부분 에서 측정하였다 [17].

비커스 경도는 하중 $10 \mathrm{kgf}$ 로 OL 시편은 ISO15156-3에 서 요구하는 위치에서 측정하였고, R3 수정용접 시험편은 수정용접부와 열영향부 위주로 측정하였다 [18]. 샤르피 충 격시험( $2 \mathrm{~mm}$ V-notch)은 ASTM A370에 따라 sub-size 시험편 $(10 \times 7.5 \mathrm{~mm})$ 으로 준비하고 $-46{ }^{\circ} \mathrm{C}$ 에서 진행하였고 가로변형량도 측정하였다. 충격 시험편의 파면은 주사전자 현미경(Scanning Electron Microscopy; SEM)와 에너지분 산 $\mathrm{X}$ 선 분석(Energy Dispersive X-ray Spectroscopy; $\mathrm{EDS})$ 을 통해 오스테나이트와 석출물 등을 확인하여 충격 인성에 미치는 영향을 확인하였다.

부식시험은 ASTM G48 Method A에 따라 $25 \times 50 \mathrm{~mm}$ 시편 크기로 edge 그라인딩과 pickling 처리하고 $6 \% \mathrm{FeCl}_{3}$ $600 \mathrm{ml}$ 용액에 $35^{\circ} \mathrm{C}$ 에서 24 시간 유지 후 무게감소 $\left(\mathrm{g} / \mathrm{m}^{2}\right)$ 를 측정하고, 육안검사와 20 배율의 광학현미경으로 공식 발생여부를 확인하였다 [19]. R3 수정용접 시험편은 $40{ }^{\circ} \mathrm{C}$ 온도 조건을 추가하여 실험하였다. 공식 발생부 주변의 상 분석은 후방산란전자 회절패턴(Electron Back Scatter Diffraction; EBSD)으로 수행하였다. $\mathrm{EBSD}$ 는 가속전압 $20 \mathrm{kV}$ 와 시험편과의 작업거리(Working Distance)를 $15 \mathrm{~mm}$ 로 설정하고 500배율 조건에서 step size $0.9 \mu \mathrm{m}$ 로 조사하 였고, 고배율의 경우 $20 \mathrm{k}$ 배율 및 step size $0.03 \mu \mathrm{m}$ 로 분석하였다.

\section{3. 결과 및 고찰}

\section{1 수정용접 재가열에 따른 미세조직 및 페라이트 분율}

그림 2(a)와 2(b)는 각각 $\mathrm{OL}$ 시험편과 R3 수정용접 시 험편에서의 미세조직 관찰 위치를 나타낸다. OL 용접 시 험편에서 위치 (1)과 (4)는 각각 용접부와 열영향부의 Cap 부분이고, 위치 (2)와 (5)는 각각 용접부와 열영향부의 Fill 부분이고, 위치 (3)과 (6)은 각각 용접부와 열영향부의 Root 부분이다. R3 수정용접 시험편에서 위치 (1), (2)와 (3)은 세 번째 수정용접부의 $\mathrm{Cap}$ 부분과 관련된 것으로 각각 모재

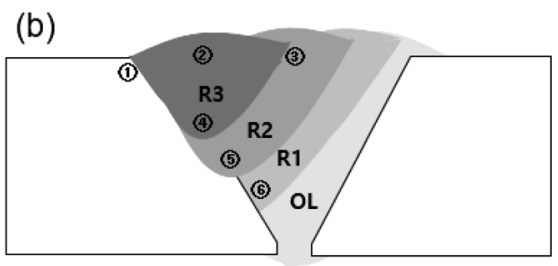

Fig. 2. Location of microstructural observation for various specimens: (a) original specimen (OL), (b) $3^{\text {rd }}$ Repair specimen (R3). 
(a)

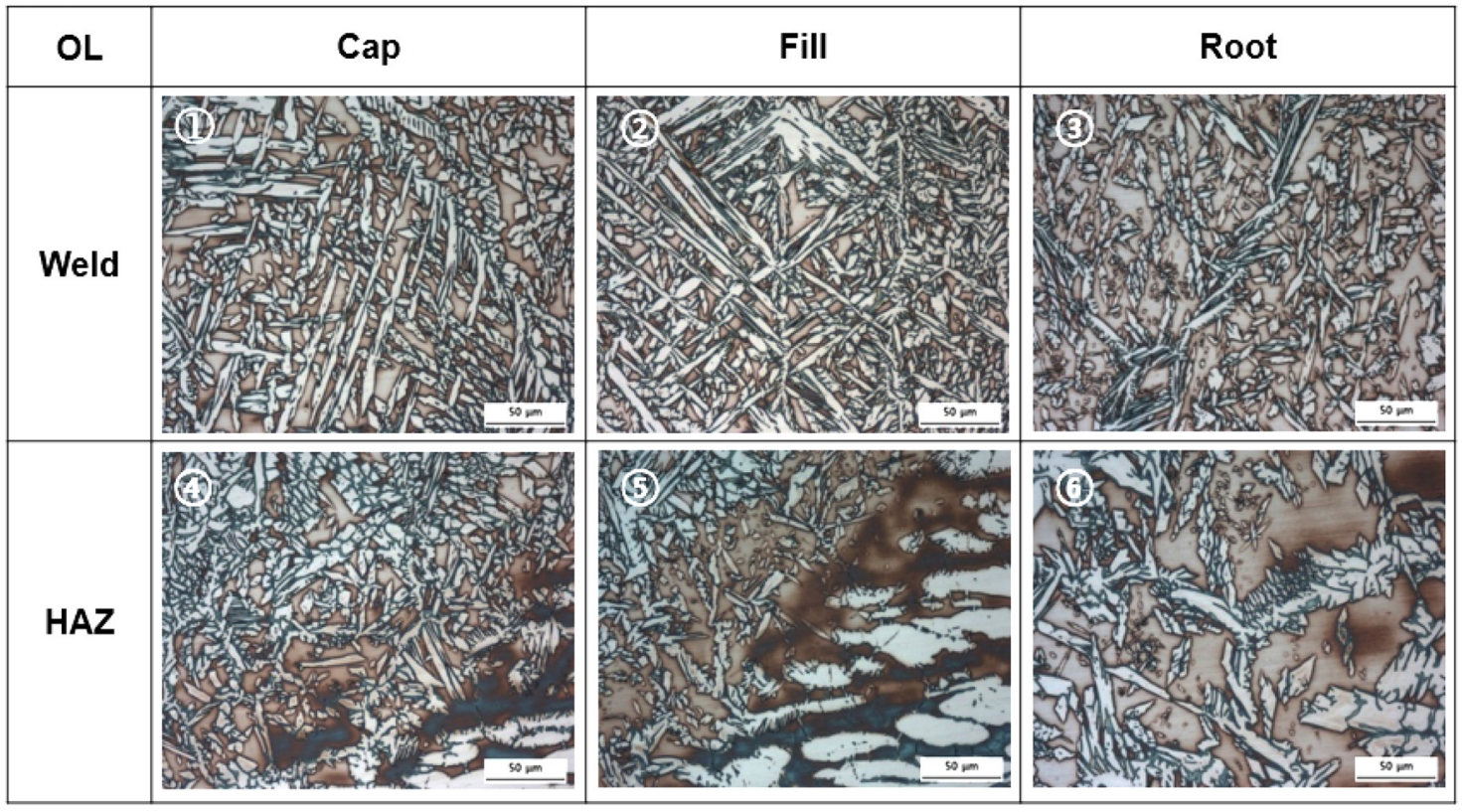

(b)

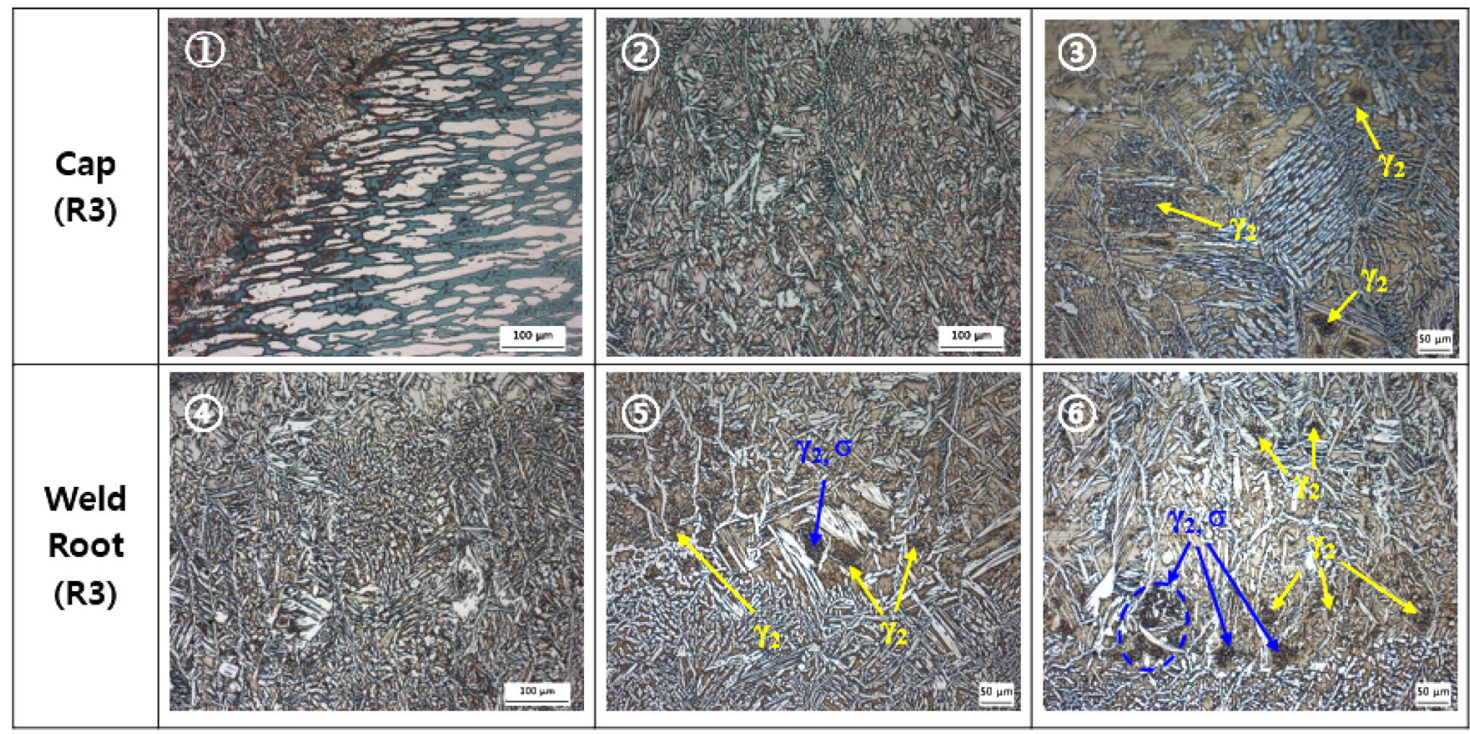

Fig. 3. Microstructure for various specimens: (a) original specimen (OL), (b) $3^{\text {rd }}$ Repair specimen (R3).

쪽 열영향부, 용접부와 두번째 수정용접부내 열영향부이며, 위치 (4), (5)와 (6)은 Root 용접부 위치로 각각 세번째 수 정용접부(R3), 두번째 수정용접부(R2)와 첫번째 수정용접 부(R1)이다.

각 위치에서의 미세조직은 그림 3에 나타내었다. $\mathrm{OL}$ 용 접 시험편의 용접부와 열영향부는 전형적인 듀플렉스 스테 인리스강의 미세조직인 페라이트(어두운 부분)과 오스테나 이트(밝은 부분)으로 이루어져 있었다. R3 수정용접 시험편
은 수정용접 시 가해진 재가열로 인해 열영향부에 좁쌀모양 의 작은 조직으로 보이는 이차오스테나이트(노란색 화살표) 가 많이 분포되어 있었다. 그 중 일부 구역에서는 시그마 상(파란색 화살표)도 함께 관찰되었다. 특히, $\mathrm{R} 1$ 수정 용 접부(6))에서 제 2 상 $\left(\gamma_{2}\right.$ 와 $\left.\sigma\right)$ 을 상대적으로 많이 확인하였다.

그림 4는 $\mathrm{Fe}-\mathrm{Cr}-\mathrm{Ni}$ 유사이원계 상태도이고, 회색 영역이 듀플렉스 스테인리스강에 해당하며 야금학적 거동과 온도 에 따른 석출 특성을 나타낸다. 페라이트는 공석반응을 통 


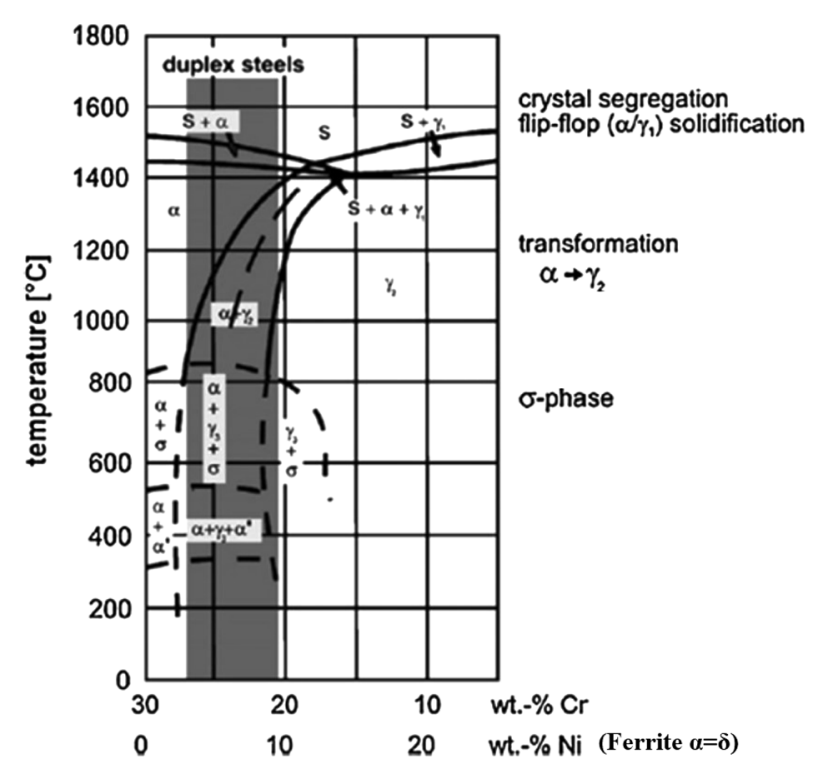

Fig. 4. Pseudo-binary Fe-Cr-Ni phase diagram for 70 wt.\% Fe [22].

Table 4. Ferrite volume fraction (\%) for various specimens and locations

\begin{tabular}{cccccccc}
\hline & (1) & (2) & (3) & (4) & (5) & (6) & Remark \\
\hline $\begin{array}{c}\text { Original } \\
\text { weld (OL) }\end{array}$ & 39.3 & 39.9 & 51.1 & 51.5 & 54.7 & 55.0 & BM: \\
$3^{\text {rd }}$ Repair (R3) & 51.7 & 51.6 & 49.8 & 38.4 & 44.4 & 41.4 & 42.1 \\
\hline
\end{tabular}

해 시그마상과 이차오스테나이트로 변태하는 것을 알 수 있다 [22,23]. 따라서, R1 수정 용접부(6))에서 더 많은 제 2 상 $\left(\gamma_{2}\right.$ 와 $\left.\sigma\right)$ 이 관찰된 이유는 반복되는 $\mathrm{R} 2, \mathrm{R} 3$ 수정용접 에 의한 재가열로 인해 특정 온도구간 $\left(320-955^{\circ} \mathrm{C}\right)$ 에서의 노출이 상대적으로 많았기 때문에, 페라이트가 이차오스테 나이트와 시그마상으로 $\left(\delta \rightarrow \gamma_{2}+\sigma\right)$ 변태되었다고 판단된 다 [20,21].

페라이트 분율은 그림 2 의 미세조직 관찰 위치와 동일한 곳에서 측정하였고, 그 결과는 표 4에 나타내었다. OL시 험편은 위치 (1)과 (2)인 용접부를 제외한 나머지 위치에서 는 모재보다 높은 페라이트 분율을 나타내었다. 위치 (3)은
용접부이지만 루트 위치라서 냉각속도가 빠르기 때문에 모 재보다 높은 페라이트 분율을 보이는 것으로 판단된다. R3 수정용접 시험편은 위치 (4)와 (6) 용접부 루트를 제외한 나 머지 위치에서 모재보다 높은 값을 보인다. 후속 용접과 반복된 수정용접이 상대적으로 많았던 수정용접 시험편에 서의 루트 용접부(위치 (4), (5), (6))는 OL의 루트 용접부(위 치 (3), (6))에서의 페라이트 분율보다 낮았고, 동일한 R3 수 정용접 시험편 내에서도 R1, R2의 루트(각각 위치 (5)와 (6)에서의 페라이트 분율이R3의 Cap부분(위치 (1), (2), (3) 에서의 페라이트 분율보다 낮았다.

그림 3의 미세조직에서 확인한 것처럼 재가열에 의해 생 성된 제2상 $\left(\gamma_{2}\right.$ 와 $\left.\sigma\right)$ 들이 페라이트 기지내 또는 페라이트와 오스테나이트 경계에서 생성되기 때문에 페라이트 분율이 낮아지는 것으로 판단된다. 하지만, Norsok M-601에서 제 시하는 용접부의 페라이트 분율의 합격 범위는 $30-70 \%$ 로 $\mathrm{OL}$ 시험편과 R3 수정용접 시험편에서의 페라이트 분율은 합격 수준을 보여준다. R3 수정용접 시험편에서 측정한 위 치 중 (1)을 제외하고는 전부 용접부이며 위치 (2)와 (4)를 제외하고는 재가열을 받은 위치였으나 모두 합격 수준으로 판단된다.

\section{2 수정용접 재가열에 따른 경도 및 충격 거동}

그림 5 는 각 시험편에서 경도 측정 위치를 나타내며, 그 결과는 표 5 에 각 시험편의 위치별로 평균 경도값으로 나 타내었다. 전반적으로 R3 시험편(그림 $5(\mathrm{~b})$ )의 경도값이 $\mathrm{OL}$ 시험편(그림 5(a))의 경도 값보다 높았다. 일반적으로 산업 규격인 ISO 15156-3과 Norsok M-601에서는 최대 경도값으로 합격 여부를 판단하지만 본 연구는 수정용접으 로 인한 재가열의 영향을 확인하기 위함이므로 경도값의 경향성 분석을 위해 평균값으로 나타내었다.

그림 6 은 표 5 의 데이터를 그래프화 하였고, 경도값은 동일 시험편에서도 루트부로 갈수록 경도가 높아지는 경향 을 보여준다. 또한 페라이트 분율과 연관해서 경도값을 비 교해보면 $\mathrm{OL}$ 시험편의 경우 페라이트 분율과 경도는 루트 부로 갈수록 증가하는 경향을 보이나, R3 시험편의 경우 (a)

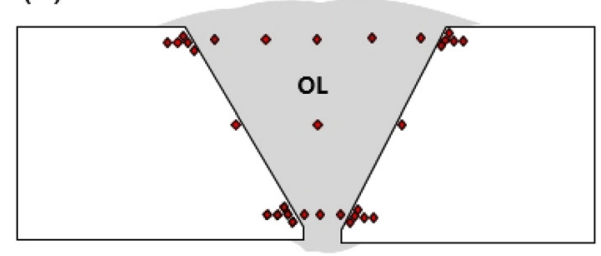

(b)

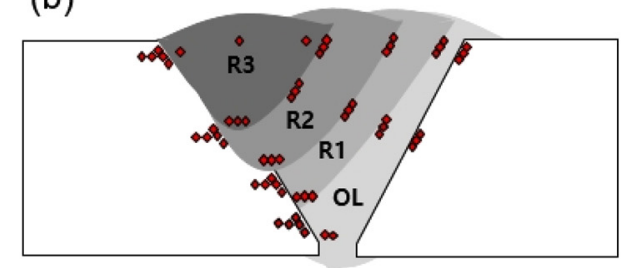

Fig. 5. Hardness location for various specimens: (a) Original specimen (OL), (b) $3^{\text {rd }}$ Repair specimen (R3). 
Table 5. Vickers hardness $\left(\mathrm{HV}_{10}\right)$ for various specimens and locations

\begin{tabular}{cccccccccccc}
\hline & \multicolumn{2}{c|}{$\begin{array}{c}\text { Original } \\
\text { Specimen (OL) }\end{array}$} & \multicolumn{9}{c}{ R3 Specimen } \\
\cline { 2 - 12 } & Weld & HAZ & Weld & HAZ & Weld & HAZ & Weld & HAZ & Weld & HAZ \\
\hline Cap & 273 & 276 & 274 & 274 & NA $^{\dagger}$ & 279 & NA $^{\dagger}$ & 277 & NA $^{\dagger}$ & 283 \\
Fill & 286 & 281 & NA $^{\dagger}$ & 278 & NA $^{\dagger}$ & 284 & NA $^{\dagger}$ & 291 & NA $^{\dagger}$ & 296 \\
Root & 276 & 285 & 274 & 289 & 301 & 289 & 307 & 291 & 311 & 311 \\
\hline
\end{tabular}

NA: Hardness was not able to be precisely measured due to the overlap of cap and fill regions.

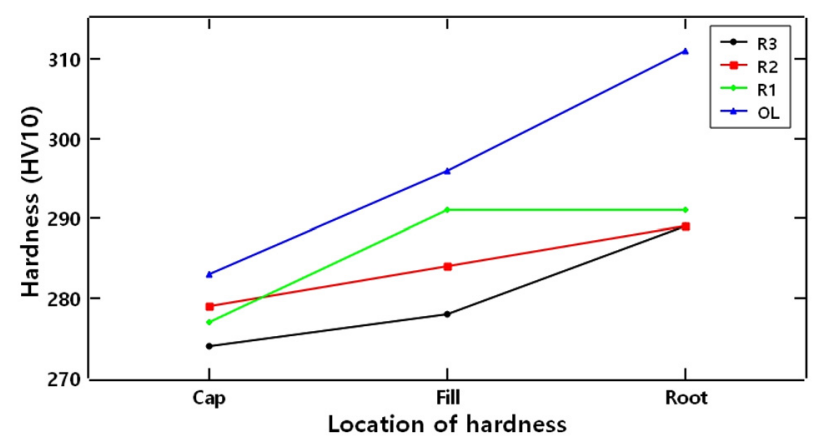

Fig. 6. Vickers hardness of HAZ for repair welding repeated to 3 times.

루트부로 갈수록 페라이트 분율은 감소하고 경도는 증가하 는 반대의 경향을 보인다. 이런 경도 증가 현상은 반복 수 정용접으로 인한 재가열로 페라이트에서 제 2 상으로 변태되 어 생성된 제 2 상의 증가, 특히 시그마상의 생성에 의해 기 인한다고 판단된다 $[10,20,21]$. 또한, 슈퍼듀플렉스 스테인 리스강의 다층 용접 루트부는 후속 용접 시 반복적인 가열 과 냉각 사이클에 의해 압축 잔류응력이 유도되어 변형 경 화(strain hardening) 가 발생한 이유도 있다 [24]. 그러나 ISO15156-3이나 Norsok M-601에서 요구하고 있는 sour service 환경에서 제한하고 있는 슈퍼듀플렉스 스테인리스 강의 최대 경도값 $\left(422 \mathrm{HV}_{10}\right)$ 보다는 모두 낮은 경도값을 나 타내어, 규격과 사양서에 만족하는 결과를 보여주었다.

그림 7은 충격시험을 위하여 R3 수정용접 시험편에서 각 수정용접부의 용융선(fusion line)을 기준으로 노치를 가 공한 모식도를 나타낸다. 각 노치의 위치에 따라 재가열 정도가 다르며, 이에 따른 충격인성의 영향을 표 6 에 나타 내었다. 충격시험은 각 위치별 $(\mathrm{a}, \mathrm{b}, \mathrm{c}, \mathrm{d}, \mathrm{e}, \mathrm{f})$ 세 개의 시험편을 제작하여 진행하였다. 모든 위치에서 충격인성은 ASTM A923 Method B에서 요구하고 있는 합격 기준치 (Min. $34 \mathrm{~J}$ )를 만족하였다.

그림 8은 표 6의 결과를 V-notch 위치별로 그래프화 시 켰고, 반복된 용접으로 인해 위치 d-f가 a-c에 비해서 충 격인성이 저하되었다. 이는 슈퍼듀플렉스 스테인리스강의 경우 과도한 입열이나 재가열에 의해 제 2 상이 석출될 수 있고 이러한 석출물로 인해 위치 $\mathrm{d}-\mathrm{f}$ 가 a-c보다 상대적으

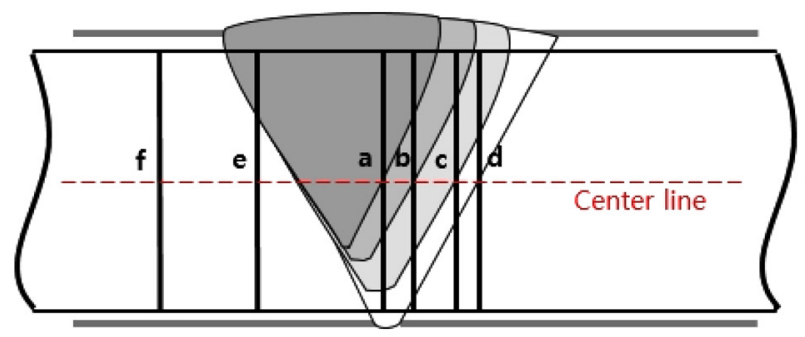

\begin{tabular}{l|ll}
\hline $\mathbf{a}$ & FL of $3^{\text {rd }}$ repair welds & (R3FL) \\
$\mathbf{b}$ & FL of $2^{\text {nd }}$ repair welds & (R2FL) \\
$\mathbf{c}$ & FL of $1^{\text {st }}$ repair welds & (R1FL) \\
$\mathbf{d}$ & FL of original welds & (OFL) \\
$\mathbf{e}$ & $\mathrm{FL}+2 \mathrm{~mm}$ of $3^{\text {rd }}$ repair welds (R3FL2) \\
$\mathbf{f}$ & $\mathrm{FL}+5 \mathrm{~mm}$ of $3^{\text {rd }}$ repair welds (R3FL5) \\
\hline
\end{tabular}

Fig. 7. Location of centerline and V-notch in the impact specimens.

Table 6. Charpy impact energy $(\mathrm{J})$ and lateral expansion $(\mathrm{mm})$ measured at various locations and at $-46^{\circ} \mathrm{C}$

\begin{tabular}{cccccccccccccc}
\hline & \multicolumn{2}{c}{ (a) R3FL } & \multicolumn{2}{c}{ (b) R2FL } & \multicolumn{2}{c}{ (c) R1FL1 } & (d) OLFL & \multicolumn{2}{c}{ (e) R3FL2 } & \multicolumn{2}{c}{ (f) R3FL5 } \\
\cline { 2 - 14 } & J & Lateral & J & Lateral & J & Lateral & J & Lateral & J & Lateral & J & Lateral \\
\hline 1 & 163 & 2.09 & 203 & 2.21 & 134 & 2.19 & 67 & 0.98 & 68 & 1.01 & 79 & 1.33 \\
2 & 152 & 2.03 & 204 & 2.39 & 168 & 2.19 & 77 & 1.21 & 82 & 1.31 & 86 & 1.47 & . \\
3 & 146 & 2.10 & 148 & 1.81 & 113 & 1.65 & 88 & 1.56 & 73 & 1.11 & 85 & 1.51 \\
\hline Avg. & 153 & 2.07 & 185 & 2.14 & 139 & 2.01 & 77 & 1.25 & 74 & 1.14 & 83 & 1.44 \\
\hline
\end{tabular}



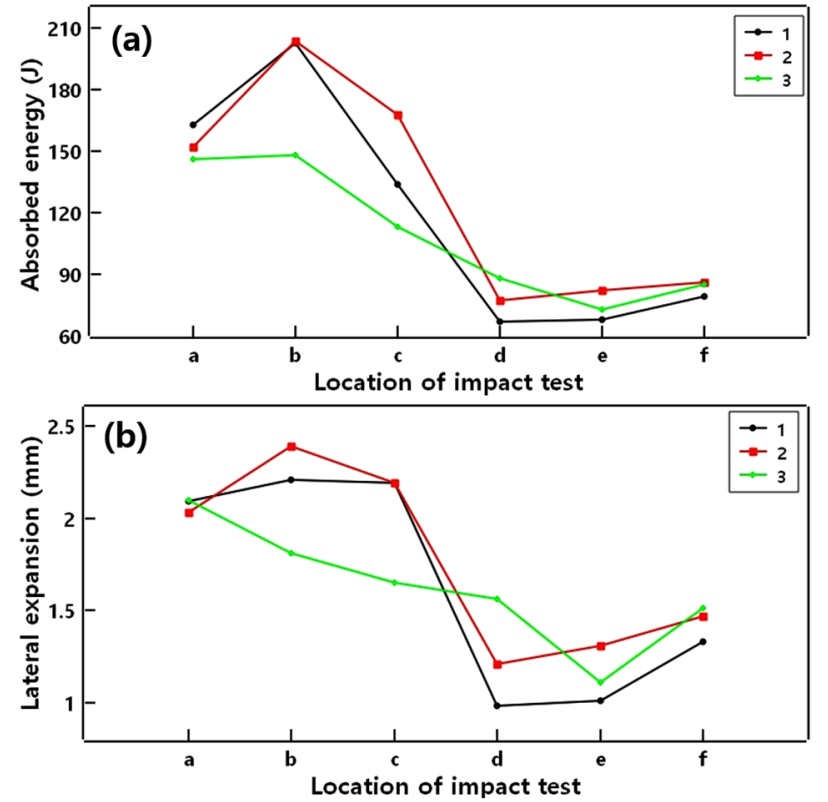

Fig. 8. Charpy V-notch results measured at various locations and at $-46^{\circ} \mathrm{C}$ : (a) absorbed energy, (b) lateral expansion.

로 재가열 받은 횟수가 많아 충격인성이 낮아진 것으로 판

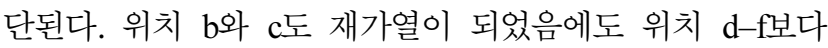
충격인성이 상대적으로 높은 이유는 다층 용접부와 재가열 에 의해서 발생한 추가 오스테나이트 생성 때문으로 판단 된다 [24].
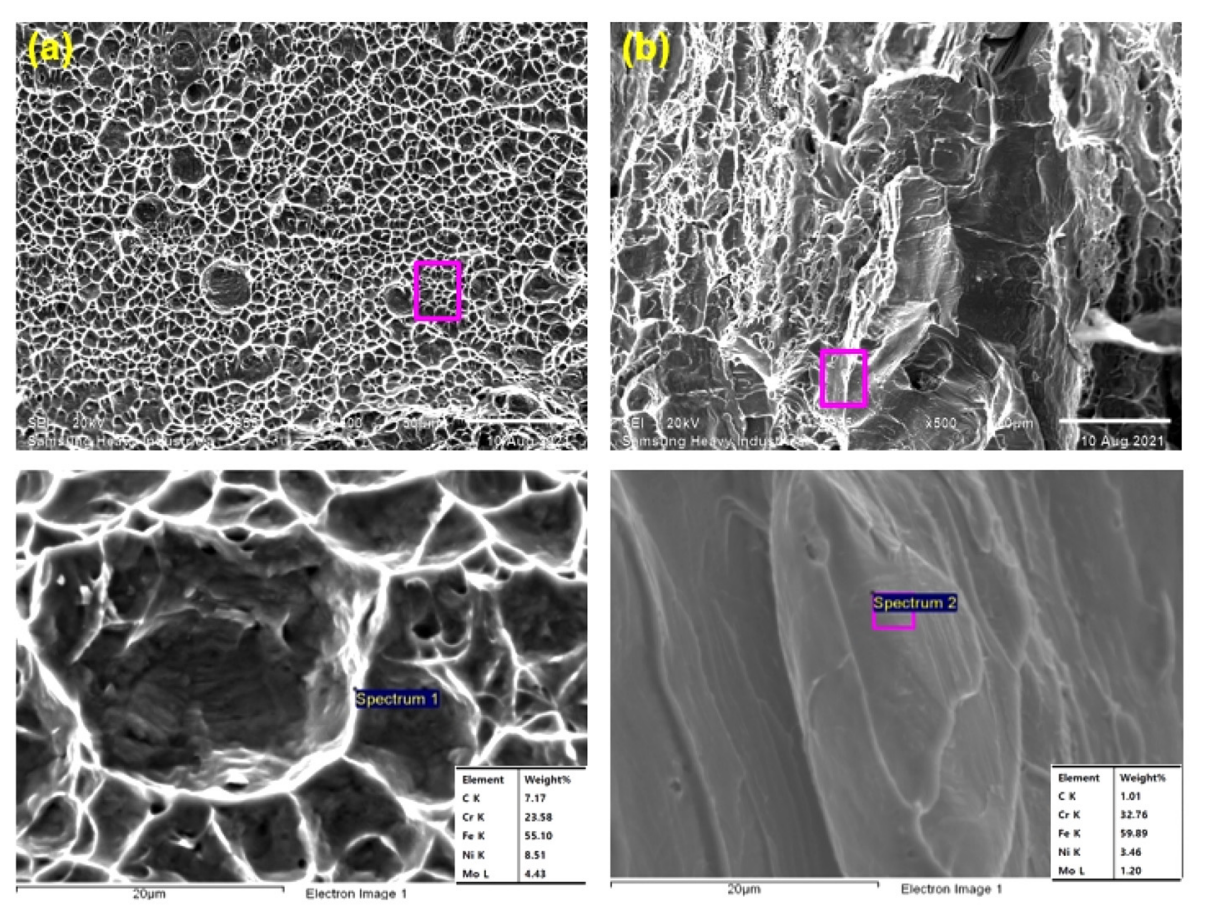

Fig. 9. SEM and EDS analysis for fractured surface of Charpy impact specimens: (a) R2FL-2 specimen, (b) OLFL-1 specimen.
충격흡수에너지의 차이 원인 분석을 위해 각각 가장 높 은 에너지 값과 가장 낮은 값을 보인 (b) R2FL-2와 (d) OLFL-1의 충격 시험편을 선택하여 SEM/EDS를 통해 파면 이미지와 화학적 성분을 분석하였다. 그림 8은 충격 시험 편 파면의 $\mathrm{SEM} / \mathrm{EDS}$ 분석 결과를 나타낸다. R2FL 시험 편은 상대적으로 많은 dimple 형태의 파면을 보이고(그림 9(a)), OLFL 시험편은 벽개파괴(cleavage) 형태의 파면을 더 많이 나타내었다(그림 9(b)). 또한 $\mathrm{EDS}$ 를 통해 분석한 파면의 성분을 기준으로 $\mathrm{R} 2 \mathrm{FL}$ 위치에서는 $23.6 \mathrm{wt} . \% \mathrm{Cr}$, $8.5 \mathrm{wt} . \% \mathrm{Ni}$ 과 $4.4 \mathrm{wt} . \% \mathrm{Mo}$ 조성의 1차 오스테나이트 (Primary austenite)가 관찰되었고, 이로 인해 충분한 충격 인성이 확보되었다. OLFL 위치에서는 $\mathrm{Cr}$ 이 $32 \mathrm{wt} . \%$ 를 초 과하는 $\mathrm{Cr}$-Rich 시그마상이 확인되었고, 이로 인해 충격인 성이 저하되는 것을 알 수 있다 [25].

\section{3 수정용접 재가열에 따른 공식 거동과 미세조직의 영향}

공식시험 결과는 표 7에 나타내었다. $\mathrm{OL}$ 시험편은 $35^{\circ} \mathrm{C}$ 에서 공식 발생이 없었으나, $\mathrm{R} 3$ 수정용접 시험편은 $35{ }^{\circ} \mathrm{C}$ 와 $40{ }^{\circ} \mathrm{C}$ 에서 모두 공식이 발생하였다. 그림 10 는 $\mathrm{R} 3$ 두 시험편 모두 첫번째 수정용접 루트 용접부에서 공 식이 발생한 것을 보여준다. 첫번째 수정용접 용융선 근처 에서 보이는 다른 하나의 공동(cavity)은 부식으로 인해 발 생한 것이 아닌 용접시 발생한 결함으로 확인하였다. 무게 
Table 7. Pitting corrosion results for various locations

\begin{tabular}{ccccc}
\hline & $\begin{array}{c}\text { Temp } \\
\left({ }^{\circ} \mathrm{C}\right)\end{array}$ & \multicolumn{2}{c}{$\begin{array}{c}\text { Weight loss } \\
\left(\mathrm{g}, \mathrm{g} / \mathrm{m}^{2}\right)\end{array}$} & $\begin{array}{c}\text { Visual and optical } \\
(\mathrm{X} 20)\end{array}$ \\
\hline Original (OL) & 35 & 0.0007 & 0.172 & No pitting \\
$3^{\text {rd }}$ Repair & 35 & 0.0016 & 0.392 & Pitting \\
$(\mathrm{R} 3)$ & 40 & 0.0021 & 0.515 & Pitting \\
\hline
\end{tabular}

감소는 보편적 합격 기준인 $4.0 \mathrm{~g} / \mathrm{m}^{2}$ 이내의 결과를 확인하 였다.

EBSD phase map은 공식의 발생 원인 분석을 위해 공 식부 주변의 페라이트/오스테나이트 분율과, 시그마상의 유 무와 위치를 확인하였다. 그림 $11(\mathrm{a})$ 와 $11(\mathrm{~b})$ 는 각각 R3$35{ }^{\circ} \mathrm{C}$ 와 $\mathrm{R} 3-40{ }^{\circ} \mathrm{C}$ 시험편의 공식부 주변의 분석 결과이다. $\mathrm{R} 3-35{ }^{\circ} \mathrm{C}$ 시험편의 경우 페라이트 분율은 $33.1 \%$ 이고, $\mathrm{R} 3-40{ }^{\circ} \mathrm{C}$ 시험편의 페라이트 분율은 $40.5 \%$ 로 확인된다. 또 한 노란색으로 표시된 시그마상은 두 시험편 모두 $0.3 \%$ 분율로 주로 페라이트와 오스테나이트 경계에서 확인되며, 이 위치는 기존의 오스테나이트와 구분이 되는 이차오스테 나이트와 동시에 발생할 것으로 판단된다. Norsok M-601 은 금속간 화합물의 총 분율을 $0.5 \%$ 이내로 규제하고 있 는데, 본 연구의 $\mathrm{R} 3-35{ }^{\circ} \mathrm{C}$ 와 $\mathrm{R} 3-40{ }^{\circ} \mathrm{C}$ 시험편은 해당 요
구조건을 모두 만족하였다. 표 4에서 확인한 R3 시험편의 페라이트 분율은 38.4-51.7\%로서, 공식부 주변의 페라이트 분율이 약간 낮음을 알 수 있다. 이는 $\mathrm{EBSD}$ 분석 영역이 ASTM E562 방법에 비하면 좁지만, 반복되는 수정 용접 에 의한 재가열로 인해 페라이트가 이차오스테나이트와 시 그마상 등으로 변태 되었고, 이러한 영향으로 무게 감소는 적으나 공식은 발생한 것으로 판단된다 [14,15,20,21].

그림 12 은 $\mathrm{R} 3-35^{\circ} \mathrm{C}$ 공식부 주변부를 고배율로 분석한 $\mathrm{EBSD}$ 결과이다. 일부 구역의 검정색으로 나타난 부분은 공식실험을 통하여 시편의 평탄도가 낮아져 $\mathrm{EBSD}$ 의 신뢰 도 지수(Confidence Index; CI)가 낮았기 때문으로 판단된 다. 따라서 $\mathrm{EBSD}$ phase map에서 정량적 상분율은 CI 0.1 미만은 분석에서 제외하였다. 그러나 시그마상 주위에 좁은 면적의 오스테나이트와 같이 존재하거나 시그마상의 석출 위치가 페라이트와 오스테나이트의 경계임을 확인 가 능하다. 따라서 공식 발생위치는 R2와 R3 수정용접 시 재 가열에 의한 R1 수정용접부로서, 제 2 상 $\left(\gamma_{2}\right.$ 와 $\left.\sigma\right)$ 의 생성이 가장 많아 내공식성이 저하된 것으로 판단된다. 3 회 수정 용접이 해양 산업에서 실제 적용하기 위해서는 제2상의 생 성을 억제할 수 있는 저입열 용접기술 또는 수정용접 시 기존 용접부를 완전히 제거하는 방법 등을 추가적으로 고
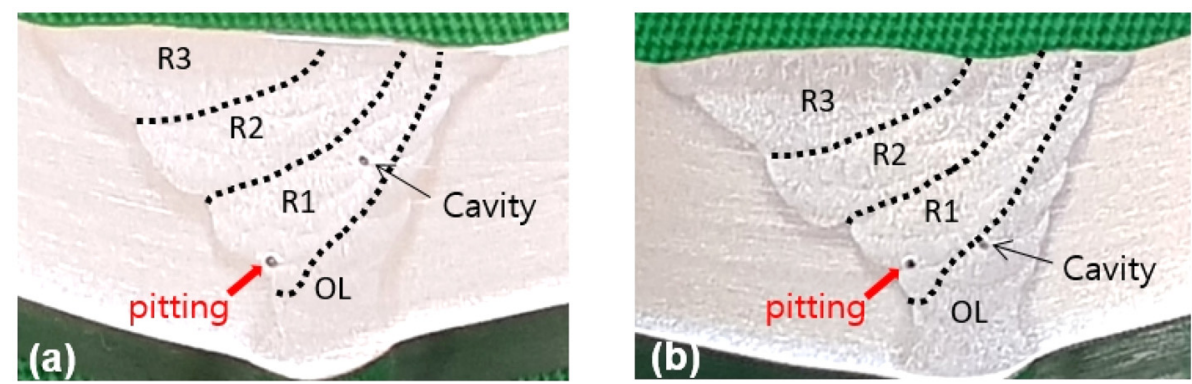

Fig. 10. Cross-sections of pitting corrosion specimens (R3) at various temperatures: (a) $35^{\circ} \mathrm{C}$ and (b) $40{ }^{\circ} \mathrm{C}$.
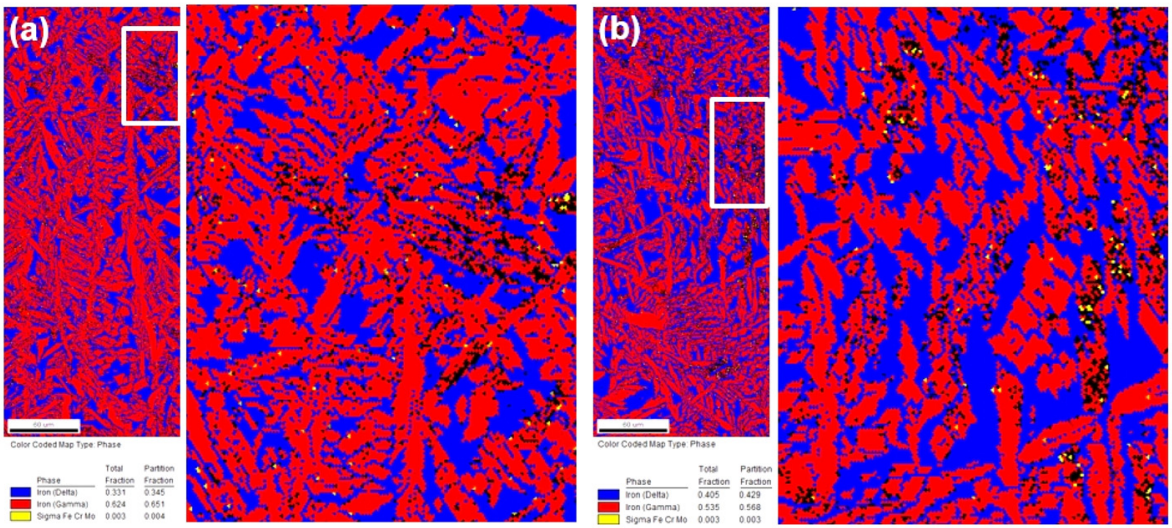

Fig. 11. EBSD phase map with IQ image for (a) R3-35 ${ }^{\circ} \mathrm{C}$ and (b) $\mathrm{R} 3-40{ }^{\circ} \mathrm{C}$ specimens. 

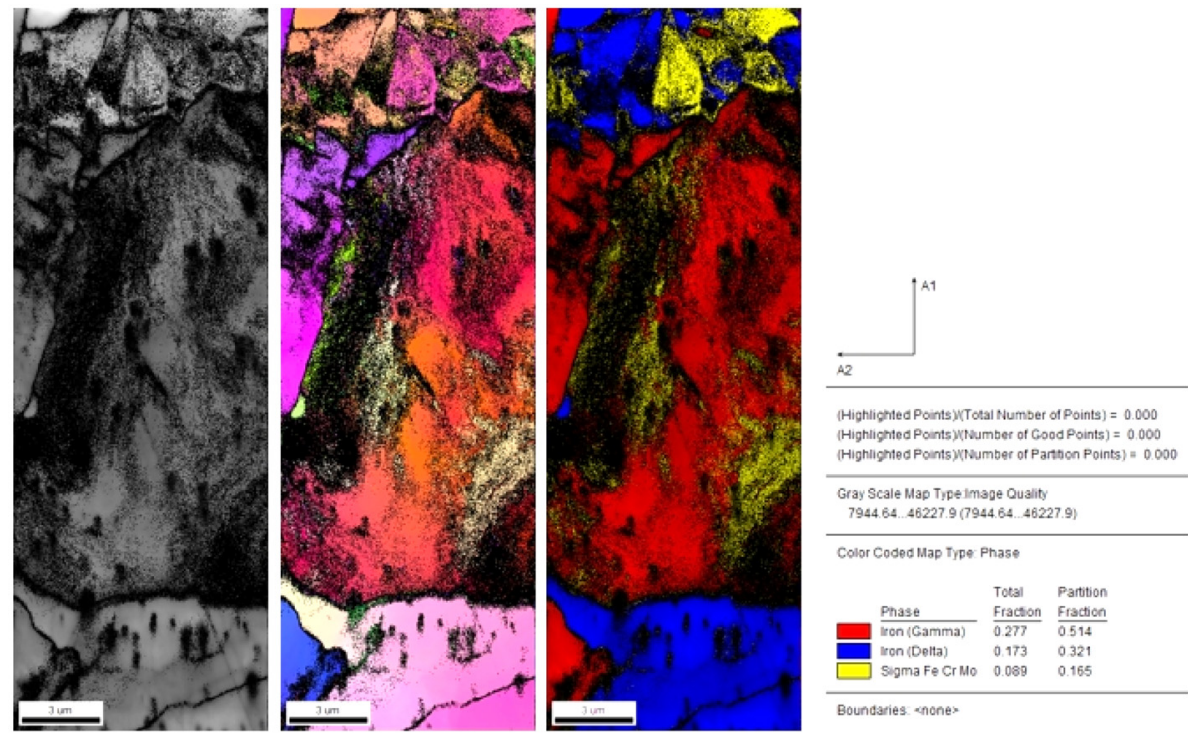

Fig. 12. EBSD map with IQ map, IPF map and IQ + Phase map for $R 3-35^{\circ} \mathrm{C}$ specimens.

려할 필요가 있다.

\section{4. 결 론}

본 연구는 슈퍼듀플렉스 스테인리스강인 UNS32750으로 수정용접을 실시하지 않은 시편과 동일 위치의 용접부에서 1-3회 수정용접을 실시한 시편을 준비하였다. 동일 위치의 수정용접이 용접부의 기계적 물성치와 내공식성에 미치는 영향에 대해 분석하기 위해 미세조직 관찰, 페라이트 분율, 경도시험, 충격시험 및 공식시험을 실시하였으며 다음과 같 은 결론을 얻었다.

1) 반복된 수정용접 시험편은 이차 오스테나이트, 시그마 상 등의 제2상이 관찰되었고, 특히 R1 수정용접부에서 상 대적으로 더 많은 제2상이 확인되었다. 이는 R2와 R3 수 정용접 시 기존 R1 용접부가 재가열되어 제2상 생성 온도 구간에서의 노출 시간이 상대적으로 더 많았기 때문이다. 페라이트 분율은 R3 시험편이 $\mathrm{OL}$ 시험편보다 상대적으로 낮았고 동일 R3 시험편에서도 재가열된 Root 용접부가 Cap 보다 더 낮았다.

2) R3 수정용접 시험편의 경도값은 $\mathrm{OL}$ 시험편보다 높았 고, 동일 시험편에서도 루트부로 갈수록 경도가 높았다. 이 는 반복되는 수정용접에 의한 재가열로 제 2 상의 생성과 후 속 용접에 의한 가열과 냉각 사이클에 의해 발생한 변형 경화에 기인한다. 그러나 본 시험의 경도값은 해양 산업에 서 요구하는 최대 경도값 이내를 만족하였다.

3) 재가열이 반복된 위치에서 충격인성은 다른 위치에 비 해 상대적으로 작았다. 이는 충격시험편 파단면 관찰에서
도 확인한 시그마상 등의 제 2 상으로 인해 충격인성이 저 하된 것으로 판단된다. 그러나 R1-R3 수정용접부의 충격 값은 해양 산업에서 요구되는 최소값을 만족하였다.

4) $\mathrm{R} 3$ 시험편은 $35^{\circ} \mathrm{C}$ 와 $40^{\circ} \mathrm{C}$ 모두 공식이 발생하였지 만, $\mathrm{OL}$ 시험편과 $\mathrm{R} 3$ 시험편의 공식시험 후 무게감소는 $4.0 \mathrm{~g} / \mathrm{m}^{2}$ 미만으로 확인하였다. 공식 발생위치는 R1 수정용 접부로 R2와 R3 수정용접 시 재가열에 의한 용접부 내 제 2 상 $\left(\gamma_{2}\right.$ 와 $\left.\sigma\right)$ 의 생성이 가장 많아 내공식성이 저하된 것 으로 판단된다. 공식 발생 위치 부근의 $\mathrm{EBSD}$ 분석을 통 해서 시그마상은 $0.3 \%$ 존재함을 확인하였다.

5) 세 번의 수정용접을 통해 기계적 물성치가 저하되는 경향은 있으나 해양 산업 요구 조건을 만족하였다. 공식시 험에서 모든 시험편의 무게감소는 요구조건을 만족하지만, 공식은 R3 시험편의 용접부 루트 1 개 지점에서 발생하였 다. 실제 해양 산업에서의 적용을 위해서는 제 2 상의 석출 물 생성을 억제하고 페라이트 분율을 제어하기 위해 용접 세부 조건(층간온도, 입열량) 관리가 필수적이며, 사전에 동 일 열이력을 재현하여 용접시방서를 작성하는 것이 필요하 다. 또한, 수정용접 시 이전의 수정용접부를 완전히 제거 가능하다면 공식의 발생 가능성도 저하될 것으로 판단된다.

\section{감사의 글}

본 연구는 2021년도 산업통상자원부 및 산업기술평가관 리원(KETI) 연구비 지원을 받아 수행되었습니다. (20010778, 20004932). 또한 본 연구에 지원 및 협조해주 
신 삼성중공업의 이상민 기능장과 $\mathrm{KOLAS}$ 연구원분들께 감사드립니다.

\section{REFERENCES}

1. B.H. Lee, H.W. Lee and Y.T. Shin, Int. J. Electrochem. Sci. 10, 7535 (2015).

2. L. van Nassau, H. Meelker, and J. Hilkes, Weld. World. 31, 322 (1993).

3. W.C. Seo, C. Park, and K.S. Bang, J. Ocean Eng. Technol. 26, 27 (2012).

4. V. Hosseini, L. Karlsson, S. Wessman, and N. Fuertes, J. Mater. 11, 933 (2018).

5. S.K. Nam, S.J. Park, H.S. Na and C.Y, Kang, J. KWJS. 28, 372 (2010).

6. V. Hosseini, M. Bermejo, J. Gardstam, K. Hurtig, and L. Karlsson, Weld. World. 60, 233 (2016).

7. D.H. Ko, Y.I. Park, and Y.T. Shin, J. Weld. Join. 38, 528 (2020).

8. W.S. Yang, W. Kil, B.R. Moon, H.B. Nam, and N.H. Kang, J. Weld. Join. 38, 400 (2020).

9. Raul Davalos Monteiro, Jan van de Wetering, Benjamin Krawczyk, and Dirk L. Engelberg, Met. Mater. Int. 26, 630 (2020).

10. M. Mousallaee and A. Babanejhad, Met. Mater. Int. 27, 2837 (2021).

11. K. Benarji, Y. Ravi Kumar, A.N. Jinoop, C.P. Paul, and K.S. Bindra, Met. Mater. Int. 27, 488 (2021).

12. H. J. Lee, S. Oh, and H. Kim, Korean J. Met. Master. 57, 51 (2019).

13. D. M. Cho, J. S. Park, W. K. Jeong, S. G. Hong, and S. J. Kim, Korean J. Met. Master. 59, 374 (2021).
14. G. Souza, A. Silva, S. Tavares, J. Pardal, M. Ferreira and I. Filho, Weld. Int. 30, 432 (2016).

15. D. Mauliddin and T. Ginta, ARPN J. Eng. Sci. 11, 11982 (2016).

16. Norsok M-601, Welding and inspection of piping, pp.13-22, Norsok standard, Norway (2016).

17. ASTM E562, Standard Test Method for Determining Volume Fraction by Systematic Manual Point Count, pp.17, ASTM, United States (2019).

18. ISO 15156-3, Petroleum and natural gas industries Materials for use un H2S- containing environments in oil and gas production, Part 3: Cracking-resistant CRAs (corrosion-resistant alloys) and other alloys, pp.33-35, ISO, Switzerland (2015).

19. ASTM G48-11, Standard Test Methods for Pitting and Crevice Corrosion Resistance of Stainless Steels and Related Alloys by Use of Ferric Chloride Solution, pp.1-11, ASTM, United States (2014).

20. D. Fellicia, Sutarsis, B. Kurniawan, D. Wulanari, A. Purniawan, and A Wibisono, IOP Conf. Ser. : Mater. Sci. Eng. 202, IOP Publishing, Indonesia (2016).

21. C. Hsieh and W. Wu, ISRN Met., 2012, pp.1-16 (2012).

22. M. Toozandehjani, K. A. Matori, F. Ostovan, F. Mustapha, N. I. Zahari and A. Oskoueian, J. Mater. Sci. 50, 2643 (2015).

23. P. Paulraj and R. Garg, Adv. Sci. Technol. Res. J. 9, 87 (2015).

24. R. Gunn, Duplex Stainless Steels, pp.146-152, Abington Publishing, Cambridge (1997).

25. R. Gunn, Duplex Stainless Steels, pp.35-41, Abington Publishing, Cambridge (1997). 